\title{
PRACTICAL CONSIDERATIONS OF THE USE OF CORTISONE AND ACTH IN RHEUMATOID ARTHRITIS* ${ }^{*}$
}

BY

\author{
R. H. FREYBERG, M. PATTERSON, C. H. ADAMS, \\ J. DURIVAGE AND C. H. TRAEGER \\ From the Hospital for Special Surgery and the Department of Medicine, \\ Cornell University Medical College, New York, N.Y.
}

The original and subsequent reports concerning the clinical effects of cortisone and ACTH (Hench and others, 1949; Thorn and others, 1949; Freyberg, 1950; Thorn and others, 1950a, b, and c; Sprague and others, 1950; Hench and others, 1950) clearly indicate that these hormones have profound effects in the human, producing great benefit on various rheumatic states so long as the hormone is administered, and that these effects cease soon after the administration of the hormones is discontinued. In acute illnesses, such as attacks of gouty arthritis or acute rheumatic fever, administration of these hormones can be expected to benefit the patient greatly, and on account of the short periods of administration there is little or no difficulty from undesired physiological effects of the hormone-producing complications. In chronic illnesses, such as rheumatoid arthritis, greater difficulties surround the use of cortisone and ACTH, for it is evident that the underlying disease process is not eliminated by a short period of administration, and prolonged vigorous use may produce serious side-effects. The practical problem, therefore, is:

How can cortisone or ACTH be effectively and safely used in patients with chronic rheumatoid arthritis?

Three possibilities exist:

(1) Administering cortisone or ACTH in short courses separated by periods of rest;

(2) Sustaining the benefits of these hormones by other forms of treatment so that cortisone or ACTH should not need to be repeated for a long period;

(3) Developing an effective method for prolonged use without harmful results.

These different methods of management were tested and compared in 31 patients

* Read at the Annual Meeting of the American Rheumatism Association, San Francisco, California, June, 1950. This paper was discussed jointly with three others at the meeting, and the complete discussion has already been reported in this Journal, 1950, 9, 394.

t These investigations were supported by the Fund for Research in Rheumatic Diseases, Hospital for Special Surgery; a grant from the Masonic Foundation for Medical Research and Human Welfare; and (in part) by a research grant from the National Institutes of Health, Public Health Service. 
with rheumatoid arthritis who received cortisone, and in 22 patients who received ACTH, during the year ending May 31, 1950. The results are summarized below.

Interval Therapy.-Using one of the hormones for a short period with rest periods intervening-so-called " course treatment" or " interval therapy"-it was hoped that undesirable side-effects would be eliminated because of interrupted treatment, that the adrenals and/or the pituitary glands might not suffer important functional or structural changes, and that with successive courses of treatment, a step-wise lasting improvement in the arthritis might be attained. In seventeen patient-experiences with interval treatment using cortisone, and in fourteen patientexperiences with courses of $\mathrm{ACTH}$, there was always significant improvement during the time the hormone was used, but in all patients relapse ensued after the hormone was stopped. No patient became increasingly better or relapsed less after successive courses.

\section{Examples.}

(i) ACTH was administered to a child aged 6, with arthritis Stage I (Steinbrocker and others, 1949); the disease quickly improved to a great degree and the erythrocyte sedimentation rate became normal. After the drug was stopped there was a prompt relapse. Reinstitution of the hormone again effected prompt improvement, but after the second course relapse again occurred, and the same thing happened a third time (Fig. 1).

(ii) A similar experience in an adult who received cortisone is illustrated in Fig. 2.

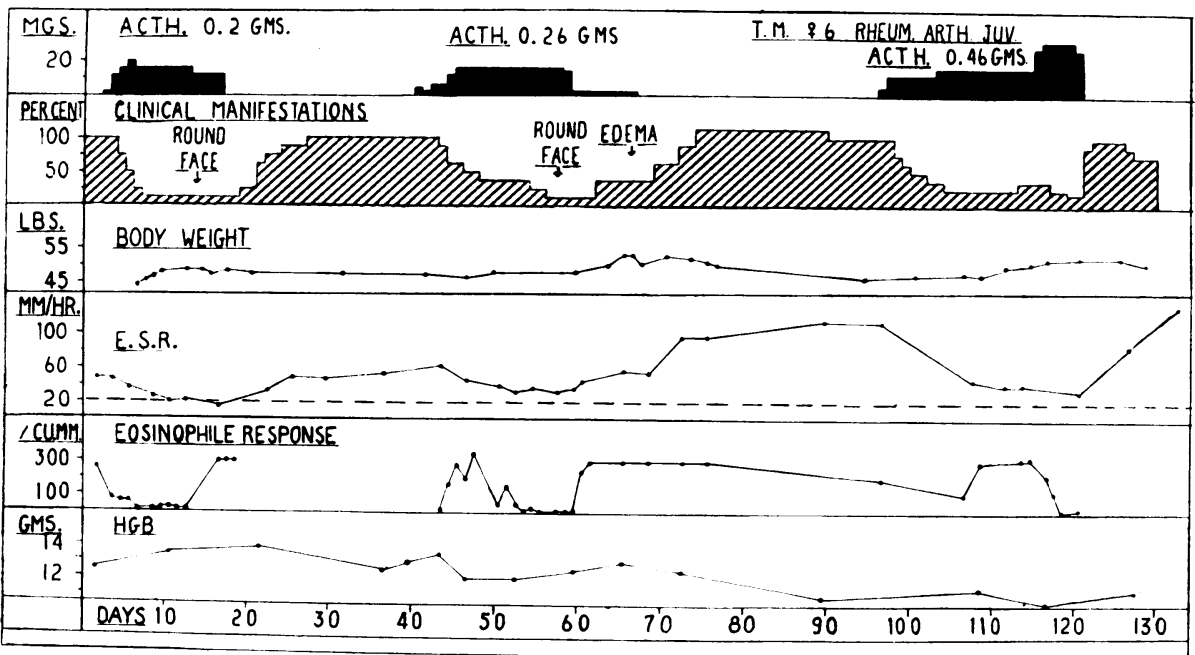

FIG. 1.-Response of a child with rheumatoid arthritis treated with "courses" of ACTH.

In all cases, short courses of hormone were well tolerated, but proved unsatisfactory since the speed and degree of relapse were unaltered after successive courses.

Efforts to Sustain Remission by Use of other Drugs.-It was hoped that after remission had been obtained by use of cortisone or ACTH, a less potent 


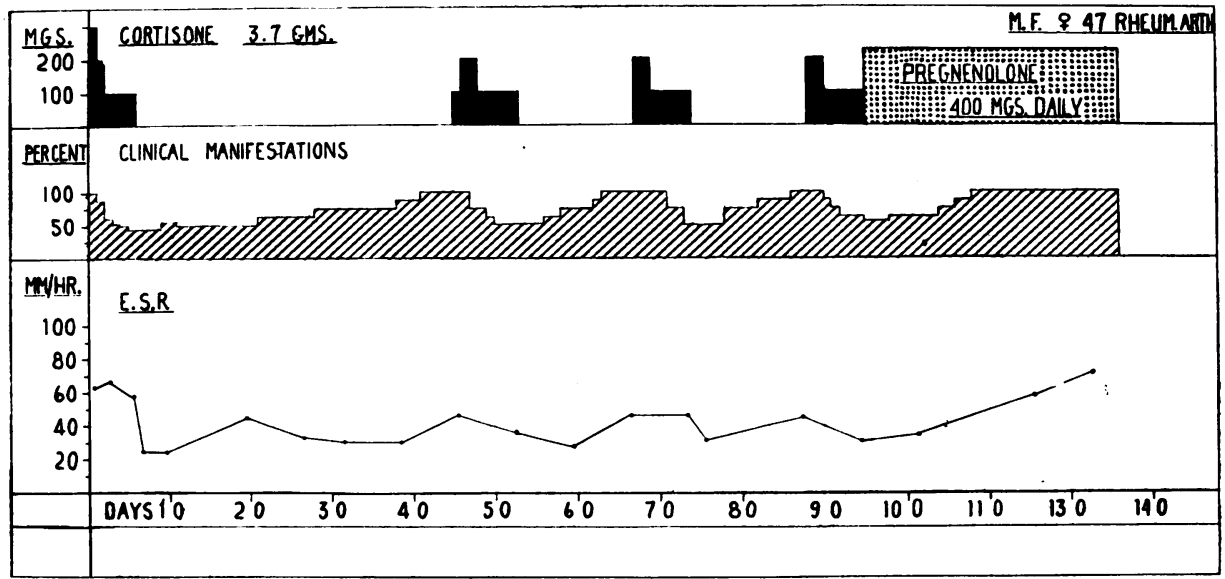

Fig. 2.-Effects of short "courses" of treatment with cortisone in an adult with rheumatoid arthritis.

anti-rheumatic drug might sustain the improvement. Several different medicines were tested for their ability to sustain remissions.

Gold.-In three patients treated with ACTH, and one treated with cortisone, gold thioglucose was injected in the customary manner after the hormone had been stopped. In one instance, benefits from the hormone (ACTH) continued for 4 weeks, then relapse began and progressed so that the pre-hormone condition was attained at the end of 8 weeks. In the other three cases, relapse began promptly after stopping the hormone and was soon complete. Used in this way gold therapy was of little or no value in preventing post-hormone relapse. Because of the slow effect of gold salts, they may be of greater benefit if begun many weeks before stopping hormone. This is now being tested.

Pregnenolone.-Results of the use of pregnenolone alone in 65 cases of rheumatoid arthritis in this clinic have been very poor. If pregnenolone had only weak anti-rheumatic effect, it might sustain the remission effected by cortisone or ACTH, but its use in this way failed completely in nine out of eleven cases in one group (Figs 2,6 , and 10). One patient retained most of the ACTH effect for 6 weeks while receiving pregnenolone orally in doses of $400 \mathrm{mg}$. daily, but then slowly relapsed.

Other Agents.-Pregnene triolone, testosterone, desoxycorticosterone acetate and ascorbic acid, and adenosine triphosphate all failed to sustain cortisone improvement (Table I).

TABLE I

EFFECT OF VARIOUS DRUǴS USED TO SUSTAIN THE EFFECTS OF CORTISONE AND ACTH

\begin{tabular}{|c|c|c|c|c|c|c|}
\hline \multirow{2}{*}{ Drug } & \multicolumn{3}{|c|}{ Cortisone } & \multicolumn{3}{|c|}{ ACTH } \\
\hline & Good & Fair & None & Good & Fair & None \\
\hline $\begin{array}{llr}\text { Pregnenolone } & . . \\
\text { Pregnene Triolone } \\
\text { Gold Salts } \\
\text { Testosterone } \\
\text { DOCA and Ascorbic } \\
\text { Docid } \\
\text { Adenosine Triphosphate }\end{array}$ & $\begin{array}{l}0 \\
0 \\
0 \\
0 \\
0 \\
0\end{array}$ & $\begin{array}{l}0 \\
0 \\
0 \\
0 \\
0 \\
0\end{array}$ & $\begin{array}{l}7 \\
0 \\
1 \\
0 \\
1 \\
0\end{array}$ & $\begin{array}{l}1 \\
0 \\
0 \\
0 \\
0 \\
0\end{array}$ & $\begin{array}{l}1 \\
0 \\
1^{*} \\
0 \\
0 \\
0\end{array}$ & $\begin{array}{l}2 \\
3 \\
2 \\
1 \\
0 \\
1\end{array}$ \\
\hline
\end{tabular}

* Sustaining effect temporary; relapse after 1 month. 
Prolonged Use of Hormone in Small Doses.-In July, 1949, studies were begun to determine three points with respect to the effects of cortisone and ACTH in patients with rheumatoid arthritis:

(1) The value of these hormones in doses less than the amount required to effect complete remission;

(2) The minimal effective dose required to sustain the desired result;

(3) The degree of safety of long-continued use of these hormones in maintenance therapy.

Three patients received ACTH, six had cortisone for more than 90 days without interruption, and three had cortisone for more than 200 days $(209,230$, and 233 respectively), It is emphasized that the plan was to effect the desired (not the maximal) degree of remission, and then to attempt to sustain the benefits with smaller amounts or less frequent injections. Examples of our results are given graphically in Figs 3 to 8.

\section{Examples.}

(i) J.M., male, aged 40 , with rheumatoid spondylitis was given only $400 \mathrm{mg}$. cortisone in 3 days; then injections of $100 \mathrm{mg}$. were made on only four, and later on only three days of each week, i.e. Monday, Wednesday, and Friday (Fig. 3). On this schedule improvement occurred so that only 40 to 50 per cent. of the clinical manifestations of disease remained. The erythrocyte sedimentation rate was reduced and the haemoglobin and weight increased. Complete remission did not occur, but improvement was considered very satisfactory by the patient. He did comfortably nearly everything he desired to do, including strenuous sports. This clinical condition

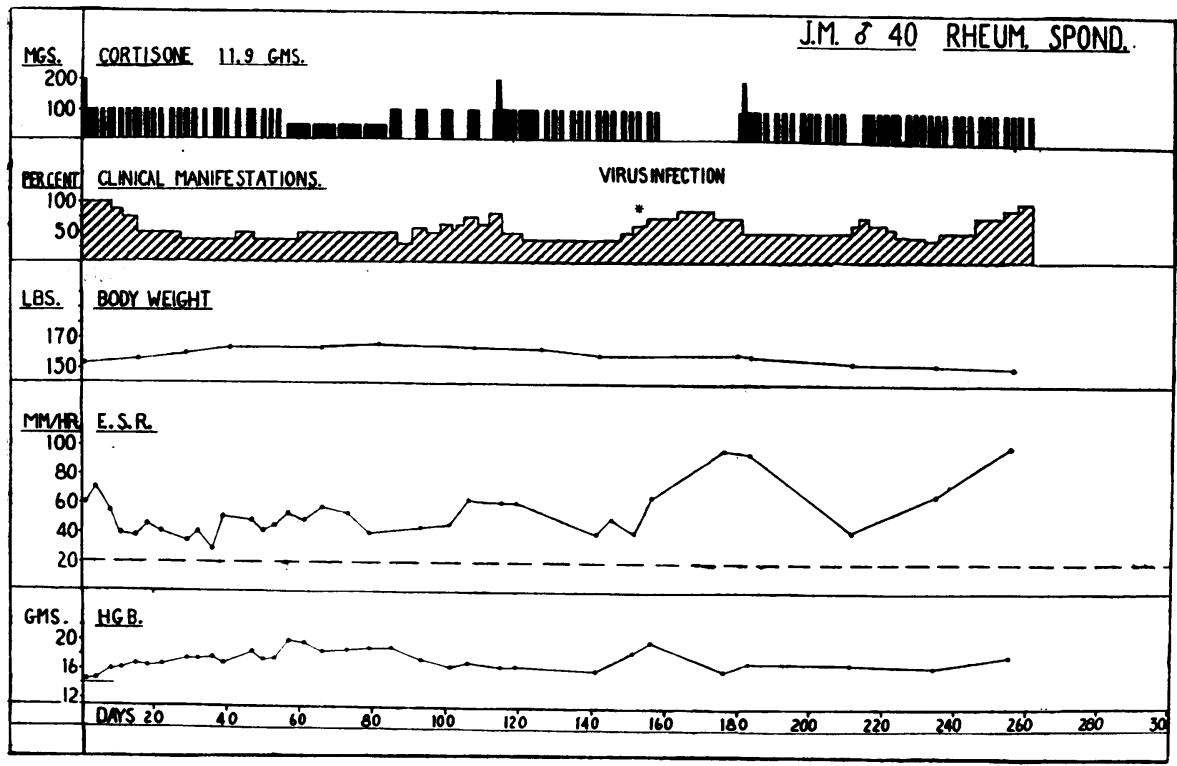

Fig. 3.-Effects of long-continued use of cortisone in an adult with rheumatoid spondylitis, showing comparative results of different dosage schedules. 
remained quite constant for 40 days, then cortisone was injected in 50-mg. doses on six days of each week for a month. There was little change, although he did not feel or function quite as well, and the erythrocyte sedimentation rate increased slightly. Then, for the next month, the same amount of cortisone was given, but it was injected in doses of $100 \mathrm{mg}$. on only the first three days of each week. His condition deteriorated more during the four days when he did not receive the hormone, than it improved when he did receive it. After a course of " booster" treatment (daily injections), the arthritis again improved to its previous state where it remained for 5 weeks, when he contracted an infection and the hormone was discontinued. After the infection subsided, cortisone was resumed, and after $700 \mathrm{mg}$. had been injected in six consecutive days, $100 \mathrm{mg}$. were injected each Monday, Wednesday, and Friday, and again good improvement was maintained for about 2 months. Then, while continuing on this same regime, he gradually relapsed completely. For this patient, the best sustaining treatment was $100 \mathrm{mg}$. cortisone injected on Monday, Wednesday, and Friday. After a long period this proved to be insufficient, and "booster" treatment was planned.

(ii) W.H., male, aged 41, with rheumatoid arthritis shows the same process even more clearly (Fig. 4). In this patient initial improvement was sustained by $100 \mathrm{mg}$. cortisone three times a week for a period of 5 weeks, after which, although the same treatment schedule was continued, he gradually grew worse. "Booster treatment", daily injections of $100 \mathrm{mg}$. cortisone for 15 days, re-established the same improvement, which was again sustained for 6 weeks by $100 \mathrm{mg}$. cortisone injected three times each week before relapse occurred. He again received the same type of booster treatment (fifteen daily injections) which produced the same degree of improvement which has continued satisfactorily for 12 weeks.

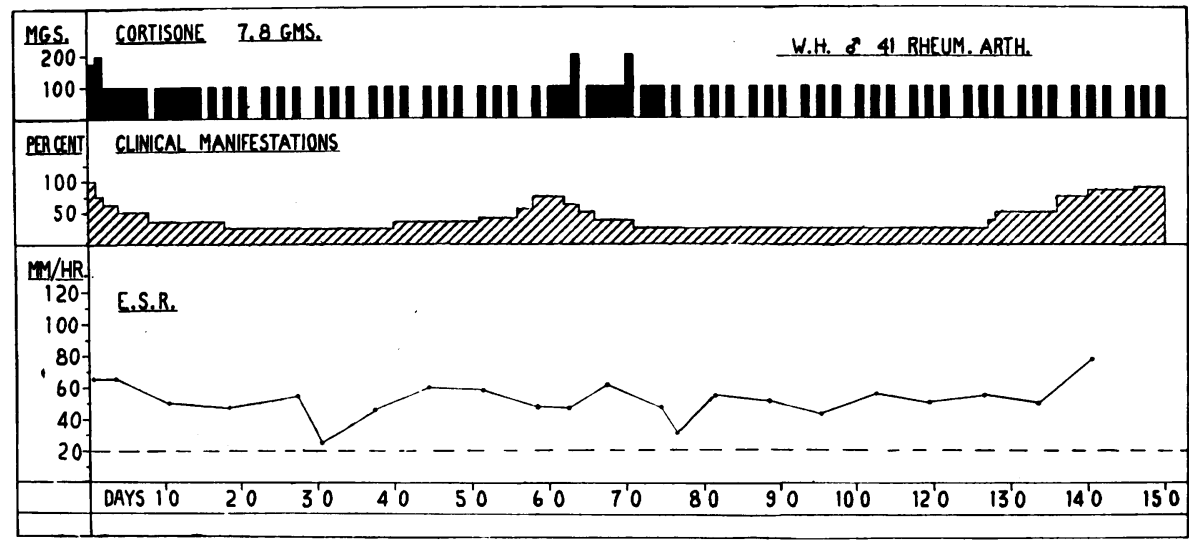

FIG. 4.-Effects of "maintenance treatment" with cortisone, and benefit from "booster" treatments, in an adult with rheumatoid arthritis.

(iii) D.D., male, aged 58, with moderately severe arthritis (Stage III) received $12 \cdot 2$ g. cortisone in two periods totalling 233 days (Fig. 5). A very good but not complete remission was accomplished by $1,750 \mathrm{mg}$. of the hormone injected during the first 13 days. This level of health, which satisfied both the patient and the physician, was nicely sustained by $100 \mathrm{mg}$. cortisone injected each second day for 105 days. As the hormone was gradually withdrawn over a 30-day period, he grew slowly but steadily worse. Without cortisone he lost all benefits, but he promptly improved greatly after the hormone was reinstituted; the improvement was again sustained by $100 \mathrm{mg}$. 
on alternate days, later three times weekly, until after 60 days the hormone was gradually withdrawn. For more than 90 days he has maintained this improvement.

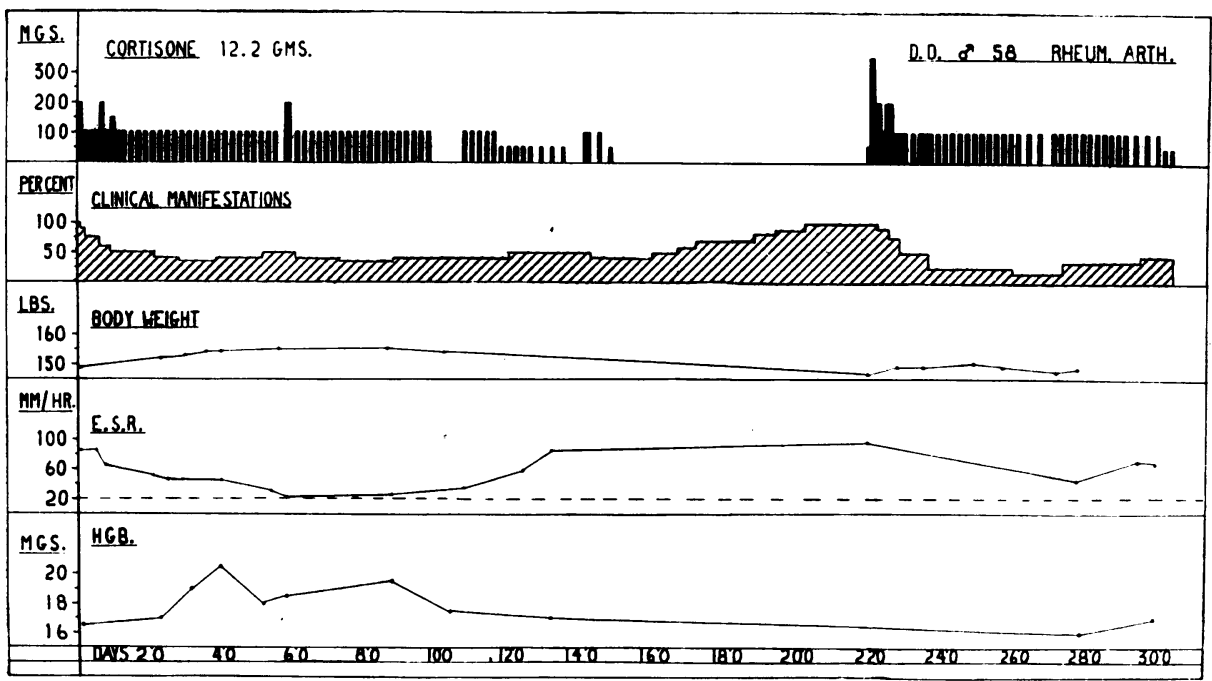

Fig. 5.-Effects of prolonged use of cortisone in an adult with rheumatoid arthritis.

(iv) M.S., female, aged 46, attained almost complete remission of arthritis (Stage II), by initial daily injections of cortisone; this improvement was sustained for 46 days by using $100 \mathrm{mg}$. cortisone three times a week. Injections of $100 \mathrm{mg}$. spaced at 5- to 7-day intervals were inadequate, she relapsed slowly but completely. Pregnenolone failed to maintain the benefits of a short booster treatment (Fig. 6).

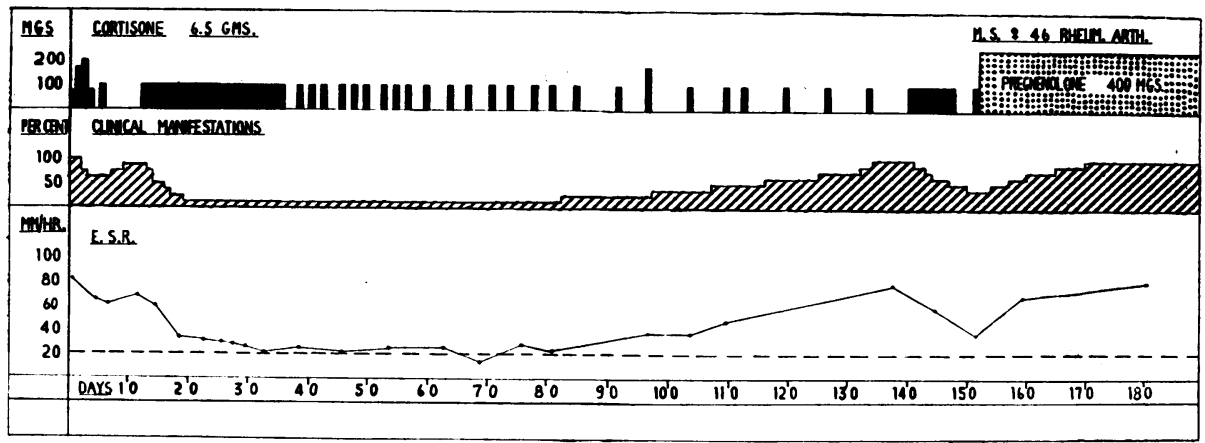

Fig. 6.-Excellent remission during "maintenance therapy" with cortisone, and failure of pregnenolone to sustain remission, in an adult with rheumatoid arthritis.

These examples illustrate that in many cases injections of cortisone given every second day, or three times weekly, may maintain a good remission of rheumatoid arthritis for many weeks. Three long-term cases to whom ACTH was administered 
required injections two or three times a day to maintain benefit. With ACTH, we had no cases of drug-fastness.

This type of long-term treatment with cortisone generally gave good results. It was also gratifying that in all instances side-effects were not encountered or were of only a minor nature. In four cases treated with cortisone as described for long periods (the longest 233 days) there were no side-reactions (Table II). Electrolyte changes, oedema, abnormalities of carbohydrate metabolism, and vasomotor effects could be readily prevented or corrected; the few side-effects encountered were all reversible, and no important nervous-system changes occurred.

TABLE II

SIDE-REACTIONS ENCOUNTERED DURING PROLONGED USE OF CORTISONE AND ACTH

\begin{tabular}{|c|c|c|c|c|c|c|}
\hline \multirow[b]{2}{*}{ Patient } & \multirow[b]{2}{*}{$\operatorname{Sex}$} & \multirow[b]{2}{*}{ Age } & \multicolumn{3}{|c|}{ Treatment } & \multirow[b]{2}{*}{ Nature of Reaction } \\
\hline & & & $\begin{array}{l}\text { Duration } \\
\text { (days) }\end{array}$ & Drug & $\begin{array}{l}\text { Dosage } \\
\text { (g.) }\end{array}$ & \\
\hline G.F. & M. & 60 & 91 & ACTH & $1 \cdot 8$ & $\begin{array}{l}\text { Oedema, mild; Tachycardia, } \\
\text { mild. }\end{array}$ \\
\hline F.S. & F. & 28 & 104 & ACTH & $3 \cdot 7$ & $\begin{array}{l}\text { Acne, moderate; Rounding of } \\
\text { face; Hirsutism; Oedema, } \\
\text { mild. }\end{array}$ \\
\hline $\begin{array}{l}\text { R.E. } \\
\text { M.S. (Fig. 6) } \\
\text { N.M. } \\
\text { W.H. (Fig. 4) } \\
\text { J.M. (Fig. 3) } \\
\text { O.S. (Fig. 7) }\end{array}$ & $\begin{array}{l}\text { M. } \\
\text { F. } \\
\text { F. } \\
\text { M. } \\
\text { M. } \\
\text { M. }\end{array}$ & $\begin{array}{l}56 \\
46 \\
59 \\
41 \\
40 \\
34\end{array}$ & $\begin{array}{l}112 \\
149 \\
150 \\
124 \\
260 \\
317\end{array}$ & $\begin{array}{l}\text { ACTH } \\
\text { Cortisone } \\
\text { Cortisone } \\
\text { Cortisone } \\
\text { Cortisone } \\
\text { Cortisone } \\
\text { ACTH }\end{array}$ & $\left.\begin{array}{r}4 \cdot 1 \\
5 \cdot 8 \\
7 \cdot 6 \\
8 \cdot 7 \\
11 \cdot 9 \\
11 \cdot 9 \\
0 \cdot 7\end{array}\right\}$ & $\begin{array}{l}\text { Rounding of face, mild. } \\
\text { None. } \\
\text { Oedema, moderate. } \\
\text { None. } \\
\text { None. } \\
\text { None. }\end{array}$ \\
\hline D.D. (Fig. 5) & M. & 58 & $\left\{\begin{array}{r}150 \\
90\end{array}\right.$ & $\begin{array}{l}\text { Cortisone } \\
\text { Cortisone }\end{array}$ & $\begin{array}{l}7 \cdot 2 \\
5 \cdot 0\end{array}$ & $\begin{array}{l}\text { Tachycardia, mild. } \\
\text { Tachycardia, mild. }\end{array}$ \\
\hline
\end{tabular}

We were particularly anxious to ascertain whether prolonged administration of cortisone might cause or allow suppression of function of the patient's adrenal glands. There was some suggestion of this in one of our cases (O.S.) to whom, after the use of cortisone for 70 days, ACTH was administered in doses of 60 to $90 \mathrm{mg}$. daily for several days, during which time there was a distinct deterioration and no apparent good effect of the ACTH (Fig. 7, p. 8). Two days and four days after cortisone had been stopped, there was no lowering of blood eosinophils after the injection of ACTH. For 30 days after cortisone was discontinued there was poor eosinophil response after ACTH stimulation, although the trend was towards improvement (Table III, p. 9). In other patients ACTH eosinophil tests showed poor adrenal response during cortisone treatment.

In one patient (M.S., example (iv) above) no eosinophil decrease occurred when tested on the 46th day of cortisone (showing no adrenal stimulation), but on the 100th day after cortisone was discontinued, there was an excellent (normal) response indicating recuperation of this adrenal function which had been lowered during the use of cortisone.

In another patient (D.D., example (iii) above) several tests of eosinophil responses following ACTH injection during prolonged cortisone therapy, showed no significant 


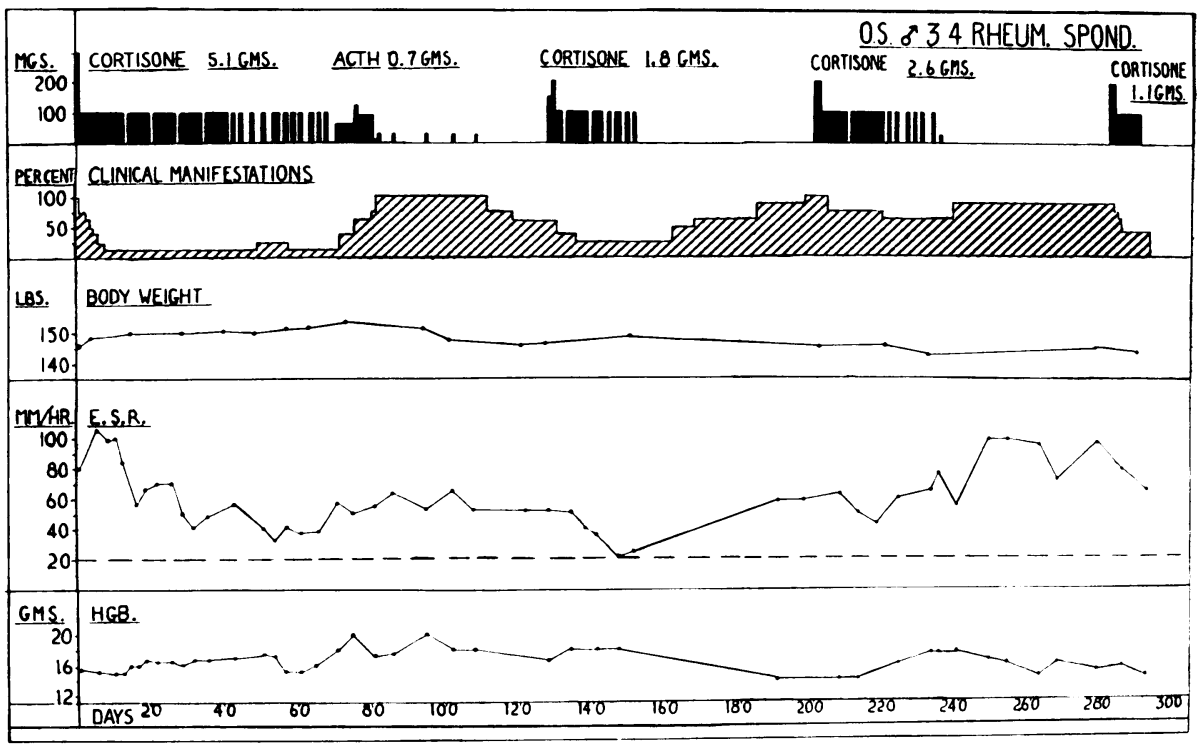

FIG. 7.-Effects of repeated use of cortisone in an adult with rheumatoid spondylitis. Note ineffectiveness of ACTH used directly after cortisone.

change, but there was progressive improvement in the eosinophil response after the hormone was discontinued, so that on the 35 th and again on the 84th day after treatment there was a normal (50 per cent.) decrease, suggesting recovery of the adrenal function measured by this test 5 to 8 weeks after the prolonged use of cortisone. At no time was there any clinical indication of hypo-adrenalism. This important problem of the effect on the adrenals of the prolonged use of cortisone is being studied further.

\section{Treatment of Children}

At the beginning of these studies we had had little experience in the treatment of children, so that the dose required was not known. To determine if the cortisone requirement in children is related to body size, a dosage formula based on the ratio of surface area was tested. Each child was given a dose corresponding to the average adult dose (100 $\mathrm{mg}$. daily) in the same ratio as its body weight corresponded to $150 \mathrm{lb}$. In all five children the results were similar.

\section{Examples.}

(i) P.S., female, aged 13, with arthritis (Stage IV), improved slightly and quite slowly on the formula dose $(67 \mathrm{mg}$. daily) compared with the usual response in adults. When the dose was doubled or tripled there was increased improvement, but sideeffects were also seen, notably round face, acne, and oedema. Later the inadequacy of $50 \mathrm{mg}$. of cortisone daily was striking; improvement followed $100 \mathrm{mg}$. daily, but even then was less than observed in many adults receiving this dose (Fig. 8, p. 10).

(ii) In one child with early, mild arthritis (Stage I), 16 to $20 \mathrm{mg}$. ACTH daily proved quite effective. 
TABLE III

EOSINOPHIL RESPONSE DURING AND AFTER ACTH STIMULATION IN PATIENTS WHO HAD RECEIVED LONG COURSES OF CORTISONE

\begin{tabular}{|c|c|c|c|c|c|c|}
\hline Patient & Sex & Age & $\begin{array}{c}\text { Cortisone } \\
\text { Administration } \\
\text { (days) }\end{array}$ & $\begin{array}{l}\text { Total } \\
\text { Amount } \\
\text { (mg.) }\end{array}$ & $\begin{array}{c}\text { Days } \\
\text { after } \\
\text { Discon- } \\
\text { tinuation } \\
\text { of } \\
\text { Cortisone }\end{array}$ & $\begin{array}{c}\text { Eosinophil } \\
\text { Reduction } \\
4 \mathrm{hrs} \text {. after } \\
25 \mathrm{mg} \text {. ACTH } \\
\text { (per cent.) }\end{array}$ \\
\hline O.S. (Fig. 7) & M. & 34 & 68 & 5,100 & $\begin{array}{r}2 \\
4 \\
7 \\
9 \\
11 \\
13 \\
22 \\
28\end{array}$ & $\begin{array}{r}-11 \\
-13 \\
28 \\
39 \\
29 \\
47 \\
30 \\
51 \text { (75 mg. ACTH) }\end{array}$ \\
\hline J.M. (Fig. 3) & M. & 40 & $\begin{array}{cc}75 & \\
77 & \\
88 & \\
\text { Second period } & 5 \\
& 6 \\
& 35\end{array}$ & $\begin{array}{r}3,800 \\
3,900 \\
4,500 \\
600 \\
700 \\
1,800\end{array}$ & $\begin{array}{c}\text { During } \\
\text {,, } \\
, \\
, \\
,\end{array}$ & $\begin{array}{l}18 \\
45 \\
26(50 \mathrm{mg} . \text { ACTH }) \\
33 \\
22 \\
34\end{array}$ \\
\hline W.H. (Fig. 4) & M. & 41 & $\begin{array}{r}65 \\
104 \\
128\end{array}$ & $\begin{array}{l}4,675 \\
6,575 \\
7,575\end{array}$ & $\begin{array}{c}\text { During } \\
, ",\end{array}$ & $\begin{array}{r}25 \\
8 \\
14\end{array}$ \\
\hline D.D. (Fig. 5) & M. & 58 & $\begin{array}{r}\text { Second period } 74 \\
87 \\
93\end{array}$ & $\begin{array}{l}4,000 \\
4,600 \\
4,800\end{array}$ & $\begin{array}{c}\text { During } \\
\dddot{4} \\
14 \\
35 \\
84\end{array}$ & $\begin{array}{r}-15 \\
10 \\
-19 \\
6 \\
59 \\
50\end{array}$ \\
\hline M.S. (Fig. 6) & F. & 46 & 148 & $\begin{array}{l}5,600 \\
6,400\end{array}$ & $\begin{array}{l}\text { During } \\
100\end{array}$ & $\begin{array}{r}-15 \\
77\end{array}$ \\
\hline
\end{tabular}

These data indicate that a child's hormone requirement is not proportional to body size, but more likely depends upon the severity of the arthritis, and may approximate to or equal the average adult requirement. In children side effects were more frequent and may be more troublesome than those encountered in adults.

\section{Oral Administration}

An important practical difficulty in the use of cortisone and ACTH in a chronic illness such as rheumatoid arthritis, is that the presently available preparations of these hormones require intramuscular injections. This makes most patients dependent upon another person for his medicine. If one of these hormones were effective orally, its clinical use would be greatly facilitated. The protein nature of ACTH makes it unlikely that it would be effective if taken into the intestinal tract. Recently, through the courtesy of Dr. James Carlisle, of Merck and Co. Inc., we had a small supply of tablets, each containing $100 \mathrm{mg}$. cortisone. The effects of these tablets were studied in four patients with rheumatoid arthritis. 


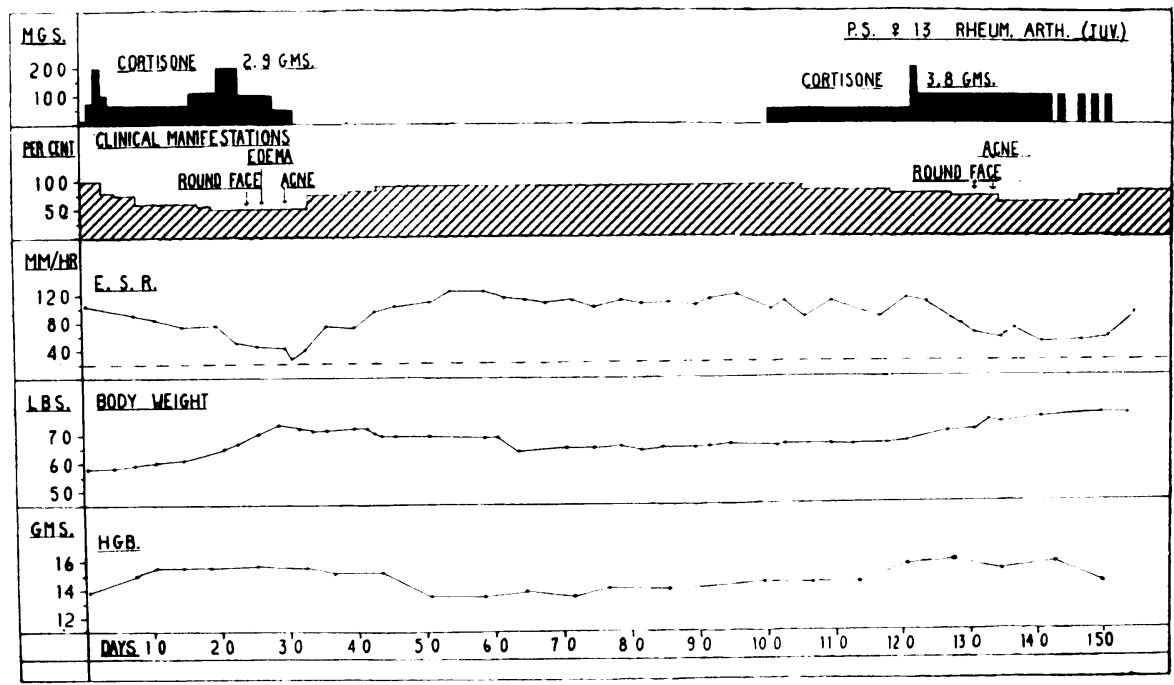

FIG. 8. -Effects of cortisone in a child with rheumatoid arthritis.

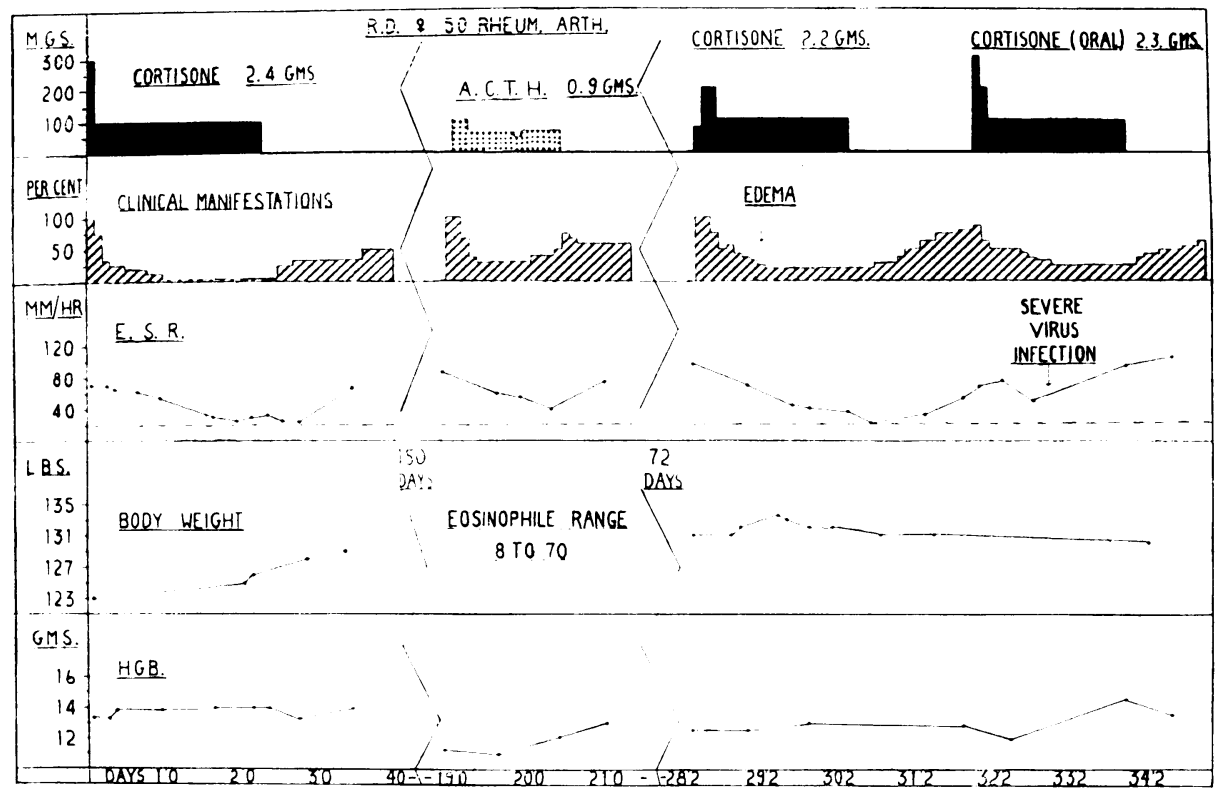

FIG. 9.-Comparison of cortisone orally with cortisone and ACTH intramuscularly in an adult Examples. with rheumatoid arthritis.

(i) R.D., female, aged 50, rheumatoid arthritis (Fig. 9), enabled us to compare the previous results of intramuscular injections of cortisone acetate suspension (two periods), and ACTH (one period). Cortisone given orally for $\mathbf{2 0}$ days in doses similar to those used parenterally, had a slightly slower, but excellent anti-rheumatic effect, even during a severe virus infection which probably kept the sedimentation rate elevated. 
(ii) E.F., female, aged 45, who had severe arthritis (Stage IV), received cortisone orally for 19 days (Fig. 10). On the first day, $300 \mathrm{mg}$. were given, on the second, $200 \mathrm{mg}$., and then $100 \mathrm{mg}$. daily. The initial anti-rheumatic effect was excellent but quickly lessened; after the daily oral dose was raised to $200 \mathrm{mg}$. there was again an excellent clinical improvement, with reduction of sedimentation rate, and increase in body weight and haemoglobin-results comparable to those usually effected by the

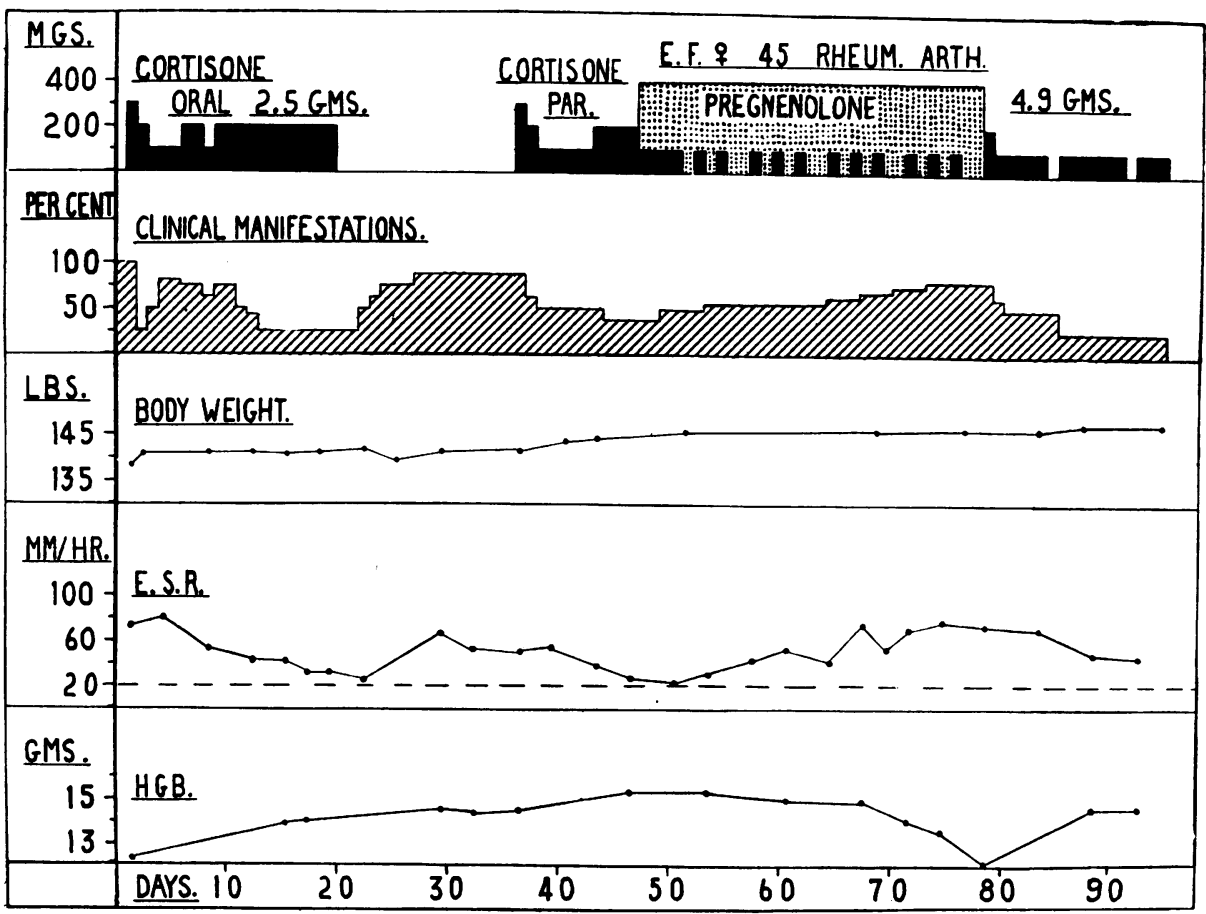

FIG. 10.-Initial good effects of cortisone orally, and comparison with subsequent use of cortisone intramuscularly and pregnenolone orally.

hormone when given intramuscularly. Relapse followed the cessation of oral therapy. With intramuscular injections of cortisone in amounts comparable to the oral doses, changes occurred similar to those produced by cortisone tablets. Benefits were not sustained by injection of $100 \mathrm{mg}$. three times weekly even though pregnenolone was used simultaneously.

Two other patients with severe arthritis (Stage IV) had good improvement from oral cortisone given for 9 days.

The effectiveness of oral cortisone has thus been demonstrated in four patients. Two patients who received the hormone by both routes, expressed preference for oral cortisone because the effect was considered to be smoother. Studies to determine the best method of oral use of cortisone are now in progress.

\section{Intra-Articular Injections}

After Hollander reported his studies of intra-articular injections of cortisone, we injected cortisone 42 times into the joints of eight patients. Amounts up to $50 \mathrm{mg}$. given intra-articularly have not irritated the joint capsule. 
Example.

F.C., male, aged 50, suffered from rheumatoid arthritis. After one injection of $25 \mathrm{mg}$. cortisone into the joint, the amount of synovial fluid decreased and the total number of cells and leucocytes in the fluid of the injected joint.were reduced in contrast to small changes in the fluid of the opposite untreated knee. With successive injections the fluid became too little to aspirate, inflammation, pain, and stiffness lessened, and

F.C., $\%, 50$, R.A., INTRA-ARTICULAR CORTISONE

\begin{tabular}{l} 
DAYS OBSERVED \\
\hline CORTISONE MG SO
\end{tabular}

Fig. 11.-Changes effected by cortisone injected intraarticularly, compared with effects of sterile saline injected for control purposes into the companion joint. Arrows indicate attempts to enter the cortisoneinjected joint which were unsuccessful because so little fluid was present within the capsule. joint function improved (Fig. 11).

These data are further indications that cortisone exerts its effect at the connective tissue level. Such intra-articular injections have been of temporary practical value to several patients and might be expected to be useful in non-articular arthritis, or in instances when one joint is the only cause for disability.

\section{Summary*}

Investigations to date indicate that cortisone and ACTH do not cure any illness, but, like other hormones, have profound pharmacologic effects. Their use is more difficult in chronic illnesses, for their desired beneficial effects may be complicated by side-reactions, some of which may be detrimental to the patient's best welfare. In patients with rheumatoid arthritis our studies indicate that variations in effect largely depend upon the amount of the dose and the manner of administration.

Repeated short periods of treatment did not result in greater or more sustained improvement after successive treatments.

To sustain the improvement effected by cortisone or ACTH, pregnene triolone, adenosine triphosphate, testosterone, pregnenolone, and gold-salt therapy begun after withdrawal of the hormone, usually failed, or were poor and undependable.

The best method of sustaining the improvement initially obtained, was to continue the use of the hormone in smaller amounts or less frequently. In several

* Since this article was written much more has been learned regarding the effects of cortisone and ACTH in patients with rheumatoid arthritis, particularly concerning the benefits and tolerance of the hormones, the complications during administration, the changes following withdrawal. We do not intend to imply that prolonged administration of cortisone and ACTH is generally recommended for rheumatoid arthritis; the exact place of these hormones in practical therapy is still to be determined. 
cases, cortisone injected three or four times weekly in doses of $100 \mathrm{mg}$., sustained good improvement.

With such maintenance therapy, the undesirable effects of the hormone were infrequent and mild even when its use was continued for 200 to 233 days. In more severe arthritis, " booster treatment" of daily injections for 5 to 14 days may be required at intervals of 4 or 5 weeks; in very severe disease, daily injections may be needed indefinitely.

The prolonged use of cortisone may suppress adrenal function; further studies are being conducted to determine the importance of this, and to ascertain the factors affecting the reversibility of this suppression. Our experience indicates that it is often better to maintain a good but not maximal anti-rheumatic effect with the least possible amount of hormone. Even after prolonged treatment, relapse tends to occur when the hormone is withdrawn. Gradual withdrawal usually affords a smoother post-hormone adjustment.

In children, hormone requirement is apparently not governed by body size, but by the severity of the disease. Doses approximating to the average adult requirement may be needed for good anti-rheumatic effect, but the problem of sideeffects then is greater.

Cortisone was shown to be an effective anti-rheumatic agent when administered orally.

Local effects were demonstrated when cortisone was injected intra-articularly.

In order to be of practical use in rheumatoid arthritis these hormones must be able to be administered easily to ambulant patients. The frequent intramuscular injections required with the present preparations complicate their prolonged use, especially that of ACTH. The demonstration of the effectiveness of cortisone given orally, and into the joint should therefore be of importance. If cortisone is prepared for oral administration, abuse of this powerful hormone must be avoided.

REFERENCES

Freyberg, R. H. (1950). Bull. N.Y. Acad. Med., 26, 206.

Hench, P. S., Kendall, E. C., Slocumb, C., and Polley, H. (1949). Proc. Mayo Clin., 24, 181.

,--1 - (1950). Ibid., 85, 545.

Hollander, J. Personal communication.

Sprague, R., Power, M., Mason, H., Albert, A., Mathieson, D., Hench, P., Kendall, E., Slocumb, C., and Polley, H. (1950). Arch. intern. Med., 85, 199.

Steinbrocker, O., Traeger, C., and Batterman, R. C. (1949). J. Amer. med. Ass., 140, 659.

Thorn, G. W., Bayles, T., Massell, B. F., Forsham, P., Hill, S., Jr., Smith, S., III, and Warren, J. (1949). New Engl. J. Med., 241, 529.

—_, Forsham, P., Frawley, T., Hill, S., Jr., Roche, M., Staehelin, D., and Wilson, D. (1950a). New Engl. J. Med., 242, 783.

$\longrightarrow,-\square, \square,-\square,-\square$ (1950b). Ibid., 242, 824.

Considérations d'Ordre Pratique sur l'Emploi de la Cortisone et de l'ACTH dans l'Arthrite Rhumatismale

RÉSUMÉ

Des recherches jusqu'à l'heure actuelle indiquent que la cortisone ou l'ACTH ne guérissent aucune maladie mais, comme toute autre hormone, ont des effets pharmacologiques profonds. Leur emploi est plus difficile dans les maladies chroniques, car l'effet favorable qu'on recherche peut se compliquer par des réactions secondaires qui pourraient porter préjudice au bien-être 
des malades. Nos études montrent que chez des malades atteints d'arthrite rhumatismale les variations de l'effet dépendent presque entièrement de la dose et du mode d'administration.

Des courtes périodes répétées de traitement ne suffisaient pas pour augmenter ou même pour stabiliser l'amélioration obtenue par le traitement initial.

Pour maintenir l'amélioration produite par la cortisone et l'ACTH, après avoir cessé leur administration, les substances suivantes furent essayées: pregnène triolone, triphosphate d'adénosine, testostérone, pregnénolone et sels d'or. Ces tentatives échouèrent ou bien aboutirent à des résultats minimes et incertains.

La meilleure méthode pour maintenir l'amélioration initiale consistait en l'emploi de l'hormone en quantité réduite ou bien aux doses plus espacées. Dans plusieurs cas l'amélioration pouvait être maintenue par des injections de $100 \mathrm{mg}$. de cortisone 3 à 4 fois par semaine.

Au cours de ce traitement de maintien des réactions secondaires à l'hormone furent rares et benignes, même quand on l'administrait pendant 200 à 300 jours. Dans des cas d'arthrite plus grave un traitement intensif d'injections quotidiennes pendant 5 à 14 jours peut être nécessaire toutes les 4 ou 5 semaines ; dans des cas très graves des injections quotidiennes s'imposent indéfiniment.

L'administration prolongée de la cortisone peut supprimer la fonction corticorénale. L'étude de ce problème continue, pour en déterminer la portée et pour trouver les facteurs qui affectent la reversibilité de ce phénomène. Nos expériences indiquent qu'il est souvent préférable maintenir un effet anti-rhumatismal bon, mais pas nécessairement le meilleur, avec la moindre quantité possible de hormone. Même après un traitement prolongé des rechutes tendent à se produire chaque fois que l'on arrête l'administration de l'hormone, mais la probabilité de la rechute diminue au fur et à mesure que le traitement se prolonge. La suppression progressive permet généralement une adaptation post-hormonale plus douce.

Chez les enfants le besoin d'hormone est apparemment déterminé non par leur taille mais par la gravité de la maladie. Pour obtenir un effet antirhumatique satisfaisant des doses approchant celles des adultes peuvent être nécessaires ; d'autre part le problème des réactions secondaires acquiert une importance plus grande.

Il a été démontré que la cortisone est efficace contre le rhumatisme quand on l'administre par la voie buccale.

On observa des réactions locales après l'administration intra-articulaire de la cortisone.

Du point de vue pratique, pour traiter l'arthrite rhumatismale, l'administration des hormones aux malades ambulants devrait être facile. La nécessité d'injections intramusculaires fréquentes des préparations employées à présent rend leur emploi onéreux, surtout en ce qui concerne l'ACTH. L'efficacité de la cortisone par la voie buccale et intra-articulaire est donc d'une grande importance. Il faudra prendre de grands soins pour éviter l'abus de la préparation orale de cette hormone puissante.

\section{Consideraciones Prácticas Sobre el Empleo de la Cortisona y de la ACTH en la Artritis Reumatoide}

\section{RESUMEN}

Las investigaciones hasta la fecha indican que la cortisona o la ACTH no curan enfermedad alguna sino, como otras hormonas, tienen hondos efectos farmacológicos. Su empleo es más difícil en las enfermedades crónicas, ya que el efecto favorable intentado puede complicarse con reacciones secundarias, con el perjuicio del enfermo. Nuestros estudios demuestran que en los artríticos reumatoides las variaciones del efecto dependen casi enteramente de la dosis y del modo de administración.

Períodos cortos y repetidos de tratamiento no bastan para aumentar y ni siquiera para estabilizar la mejoría obtenida con el tratamiento inicial.

Para mantener la mejoría producida por la cortisona y por la ACTH despuès de haber interrumpido la administración de éstas, fueron empleados : pregnene triolone, trifosfato de adenosina, testosterona, pregnenolona y sales de oro. Estas tentativas fracasaron o dieron resultados mínimos e inseguros.

El mejor método para mantener la mejoría inicial producida por la cortisona y la ACTH consistía en administrar la hormona a intervalos más largos o en cantidades reducidas. En muchos casos 3 o 4 inyecciones por semana de $100 \mathrm{mg}$. de cortisona bastaban para mantener la mejoría.

En el curso del tratamiento de sostén las reacciones secundarias a la hormona fueron raras y benignas, aun cuando la administración había durado 200 a 300 días. En casos de artritis grave se puede necesitar un tratamiento de choque de 5 a 14 inyecciones diarias consecutivas cada 4 o 5 semanas ; en casos muy graves inyecciones diarias habrán de continuarse indefinidamente.

La administración prolongada de la cortisona puede suprimir la función adrenal. Este problema está al estudio para determinar su importancia y para hallar los factores interesados en la reversibilidad del fenómeno. Según nuestra experiencia, a menudo más vale mantener un efecto anti-reumático bueno, pero no el mejor, con la menor posible cantidad de hormona. Aun después del tratamiento prolongado, al cesar la administración de la hormona, recaídas suelen producirse, 
pero cuanto más dura el tratamiento tanto menos posible es la recaída. La privación gradual permite generalmente una adaptación post-hormonal más suave.

En los niños el requerimiento de hormona no parece estar determinado por el tamaño del cuerpo sino por la gravedad de la enfermedad. Para obtener un efecto anti-reumático satisfactorio se pueden necesitar dosis casi tan fuertes como las para adultos ; aquí la cuestión de las reacciones secundarias adquiere mayor importancia.

Se ha demostrado la eficacia antirreumática de la cortisona por la vía oral.

Después de la administración intra-articular de la cortisona fueron observadas reacciones locales.

Desde el punto de vista práctico, para tratar la artritis reumatoide es preciso que estas hormonas se puedan administrar facilmente a enfermos ambulantes. La necesidad de inyecciones intramusculares frecuentes de las preparaciones empleadas hasta ahora complica su empleo, particularmente cuando se trata de la ACTH. El hecho que la cortisona es eficaz por vía oral e intra-articular tiene, por consiguiente, gran importancia. Habrá que tener mucho cuidado con la preparación oral para evitar el abuso de esta hormona poderosa. 